\title{
Bacterial production of marine humic-like fluorescent dissolved organic matter and its biogeochemical importance
}

\author{
Koichi Shimotori, Yuko Omori, Takeo Hama* \\ Graduate School of Life and Environmental Sciences, University of Tsukuba, Tsukuba, Ibaraki 305-8572, Japan
}

\begin{abstract}
Bacterial production of humic-like fluorescent dissolved organic matter $\left(\mathrm{FDOM}_{\mathrm{H}}\right)$ was examined in a $90 \mathrm{~d}$ culture experiment using a bacterial assemblage collected from coastal water with artificial seawater amended by glucose. A rapid decrease in dissolved organic carbon concentration was noticed during Days 1 to 5, and this coincided with an increase in bacterial numbers. The increase in $\mathrm{FDOM}_{\mathrm{H}}$, which was determined by Excitation-Emission Matrix Spectroscopy (EEMS), was observed by Day 20, showing the production of $\mathrm{FDOM}_{\mathrm{H}}$ by bacteria. This increase lagged behind the increase in bacterial numbers, suggesting that the production of $\mathrm{FDOM}_{\mathrm{H}}$ was accompanied by an alteration of bacterial biomolecules. After Day 30, the fluorescence intensity showed no significant decrease, and $63 \%$ of the maximum intensity on Day 20 remained at the end of the experiment. This high remaining percentage likely reflects the recalcitrant properties of bacteria-derived FDOM $_{\mathrm{H}}$ $\left(\mathrm{BAC}-\mathrm{FDOM} \mathrm{H}_{\mathrm{H}}\right)$. High-performance size-exclusion chromatography with fluorescence detection $($ Excitation/Emission $=335 / 410 \mathrm{~nm})$ revealed that most of BAC-FDOM $\mathrm{H}_{\mathrm{H}}$ is composed of 3 molecular weight (MW) groups having similar fluorescent properties. The MWs of these were all $<1.8 \mathrm{kDa}$ relative to standards with known MW. A photodegradation experiment of $\mathrm{BAC}-\mathrm{FDOM}_{\mathrm{H}}$ demonstrated that the photodegradability of fluorophores varied among the MW groups. Measurements of the MW composition of coastal seawater showed that a recalcitrant fraction of BAC-FDOM $\mathrm{H}_{\mathrm{H}}$ resistant to solar irradiance constituted a part of $\mathrm{FDOM}_{\mathrm{H}}$ in ambient seawater.
\end{abstract}

KEY WORDS: Dissolved organic matter - Fluorescent dissolved organic matter - Humic-like substance $\cdot$ Bacteria $\cdot$ Excitation-Emission Matrix Spectroscopy $\cdot$ High-performance size-exclusion chromatography

\section{INTRODUCTION}

Marine dissolved organic matter (DOM) is among the largest reservoirs of reduced carbon on the surface layer of the earth (Hedges 1992). Recent studies have revealed that the major part of oceanic DOM is composed of microbiologically refractory DOM (R-DOM), with labile DOM (L-DOM) accounting for only a minor part (Amon \& Benner 1994, Benner 2002). Major organic compounds newly fixed by phytoplankton photosynthesis are presumably susceptible to microbial decomposition. The production of recalcitrant organic compounds through microbial metabolism is one of the most dominant processes in the conversion of labile compounds into refractory ones (Ogawa et al. 2001, Hama et al. 2004, Kaiser \& Benner 2008), although photochemical production of recalcitrant DOM has also been reported (Obernosterer et al. 1999).

Humic substances are complex, heterogeneous mixtures of organic matter and are considered to be among the main components of R-DOM (Aiken et al. 1985). They represent a significant proportion of carbon and nutrient storage and also absorb ultraviolet (UV) rays, thereby protecting marine organisms against UV damage (Nielsen \& Ekelund 1993). Mea- 
surements of fluorescence of humic substances are simple and have been widely used to determine them, mainly due to their high sensitivity (Chen \& Bada 1992, Coble et al. 1998). In particular, the development of Excitation-Emission Matrix Spectroscopy (EEMS), in which a 3-dimensional contouring intensity landscape appears as a fingerprint, provides significant information on the major components of fluorescent DOM (FDOM), such as humic-like, marine humic-like, and protein-like substances (Coble et al. 1998, Parlanti et al. 2000, Stedmon et al. 2003). The distribution of FDOM corresponding to humic-like substances $\left(\mathrm{FDOM}_{\mathrm{H}}\right)$, which has peaks within excitation $(\mathrm{Ex}) /$ emission $(E m)=290-360 / 370-480 \mathrm{~nm}$ in marine environments, has been measured, and both spatial (Parlanti et al. 2000, Chen et al. 2007) and vertical (Chen \& Bada 1992, Yamashita \& Tanoue 2004a) distributions have been determined.

Simultaneously with these efforts to obtain the distributions of $\mathrm{FDOM}_{\mathrm{H}}$, approaches to elucidating its composition have also been developed. One of the most significant findings in the recent study of oceanic DOM is that the low molecular weight (MW) fraction of oceanic DOM is mainly composed of microbial refractory compounds (Amon \& Benner 1994, Hama et al. 2004). This strongly suggests that MW composition is important in the assessment of the biogeochemical properties of DOM. Thus, the MW distribution of $\mathrm{FDOM}_{\mathrm{H}}$ should provide useful information to elucidate biogeochemical features. The separation of FDOM $_{\mathrm{H}}$ using ultrafiltration has revealed that most oceanic FDOM in the marine environment is mainly found in low-MW fractions (Midorikawa \& Tanoue 1998, Yamashita \& Tanoue 2004a). High-performance size-exclusion chromatography (HPSEC) is the standard method used to separate humic substances dissolved in fresh water, and many relevant studies have been carried out (e.g. Chin et al. 1994, Peuravuori \& Pihlaja 1997). For seawater, however, few attempts have been made (Parlanti et al. 2002, Dittmer \& Katter 2003), mainly due to the effect of sea salts on the elution pattern.

The characteristic vertical distribution of FDOM $_{H}$ with low concentration in the surface layer and high in the mid-deep layers (Chen \& Bada 1992, Yamashita \& Tanoue 2008) has generated questions about the sources and sinks of FDOM $_{\mathrm{H}}$. The compatibilities of the profiles of $\mathrm{FDOM}_{\mathrm{H}}$ intensity and the concentration of inorganic nutrients (Chen \& Bada 1992, Yamashita et al. 2007) suggest that the production of FDOM $_{\mathrm{H}}$ is associated with the decomposition of organic matter. An experimental approach using microbial populations found a positive relationship between FDOM $_{\mathrm{H}}$ intensity and bacterial abundance, indicating a bacterial contribution to the production of FDOM $_{\mathrm{H}}$ (Nelson et al. 2004, Steinberg et al. 2004). However, microbial populations used for such experiments contain microorganisms other than bacteria, such as phytoplankton (Nelson et al. 2004) and zooplankton (Steinberg et al. 2004). Several experimental studies which only used a bacterial population (e.g. Kramer \& Herndl 2004, Stedmon \& Markager 2005) indicate that bacteria are one of the most importance sources of oceanic FDOM $_{\mathrm{H}}$.

However, the relative importance of bacteria, phytoplankton and zooplankton as producers of FDOM $_{\mathrm{H}}$ remains cotroversial because it depends on the area or depth in the ocean. Aside from the production processes of FDOM $\mathrm{F}_{\mathrm{H}}$, photodegradation by solar radiation has been found responsible for its decomposition (Mopper et al. 1991). The experimental approaches of Moran et al. (2000), Kramer \& Herndl (2004) and Stedmon \& Markager (2005) have also ascertained that the decrease in fluorescence intensity is due to irradiation. However, only the changes in fluorescence intensity in seawater samples without any fractionation have been measured so far, while the variations in photodegradability among the compositional fractions of $\mathrm{FDOM}_{\mathrm{H}}$ have yet to be considered.

In the present study, the bacterial assemblage collected from coastal water was incubated in a culture medium composed basically of artificial sea water and glucose. Excitation-emission matrices (EEMs) of the culture medium were measured to elucidate the pro-

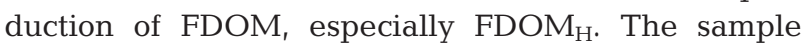
water was first desalted by electrodialysis, and the bacteria-derived FDOM $_{\mathrm{H}}\left(\mathrm{BAC}_{\mathrm{FDOM}}\right)$ was separated by HPSEC, with respect to its MW to assess the MW composition. A photodegradation experiment was also carried out to elucidate the difference of light susceptibility among each MW fraction of BAC-FDOM $\mathrm{H}_{\mathrm{H}}$. The results of the incubation, EEMS, HPSEC, and the photodegradation experiments are discussed from the aspect of the importance of bacterial contribution to the production source of $\mathrm{FDOM}_{\mathrm{H}}$ in the coastal zone.

\section{MATERIALS AND METHODS}

Marine bacterial assemblage. Surface seawater was collected from Oura Bay, located in Shimoda, Shizuoka, Japan, on 11 January 2007. Natural water exuding from the rock cliffs along the shoreline of the bay was also collected to investigate the influence of terrestrial FDOM $\mathrm{F}_{\mathrm{H}}$. The water flow from the upper part of the cliffs, where dense broad-leaved forest develops, was continous and thus we regarded the exuded water as a forest effluent sample. These water samples were filtered through a precombusted $\left(450^{\circ} \mathrm{C}, 4 \mathrm{~h}\right)$ glass fiber filter (GF/F, Whatman) to remove the particulate mat- 
ter, including zooplankton and phytoplankton. This filtrate was used as an inoculum for the marine bacterial assemblage in our incubation experiment.

Incubation experiment. Artificial seawater (compositional ratio: $\mathrm{NaCl}, 120.0$ g; $\mathrm{MgCl}_{2}, 54.3 \mathrm{~g}_{i} \mathrm{Na}_{2} \mathrm{SO}_{4}$, $20.0 \mathrm{~g} ; \mathrm{KCl}, 3.4 \mathrm{~g}$ ) was prepared and adjusted to $30 \%$ with Milli-Q water. The DOC concentration of $30 \%$

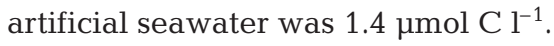

Artificial seawater $(30 \%, 19$ l) was inoculated with the marine bacterial assemblage (1 ll) in $23 \mathrm{l}$ acidcleaned polycarbonate bottles to which we also added glucose, $\mathrm{NaNO}_{3}$, and $\mathrm{Na}_{2} \mathrm{HPO}_{4}$ at final concentrations

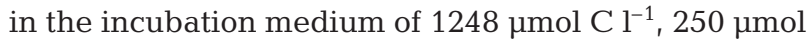
$\mathrm{N}^{-1}$, and $25 \mu \mathrm{mol} \mathrm{P}{ }^{-1}$, respectively. Duplicate incubation bottles were prepared. After the addition of organic matter and inorganic nutrients, a subsample (Day 0) was collected and filtered through a $0.2 \mu \mathrm{m}$ pore size alumina filter (Anodisc, Whatman) to separate the organic matter into DOM (filtrate sample) and particulate organic matter (POM) (filter sample). The sample for the bacterial count was also collected from both incubation bottles, and glutaric aldehyde was immediately added to fix the bacteria. The incubation medium was kept at $20^{\circ} \mathrm{C}$ for $90 \mathrm{~d}$ in the dark. Subsamples were collected on Days 1, 2, 3, 5, 10, 20, 30, 60, and 90 . The sample treatments were the same as those in the sample of Day 0. The control sample with $30 \%$ artificial seawater used to inoculate only the marine bacterial assemblage ( $5 \%$ of total volume) was also incubated, and subsamples were collected as described above.

Determination of DOC, POC, and particulate organic nitrogen (PON) concentrations. DOC concentrations in the filtrate samples were measured by a high-temperature catalytic oxidation method (Sharp et al. 1993) using the Shimadzu TOC-5000A. The system was standardized before measurement with potassium hydrogen phthalate. The concentration of POC and PON collected onto an anodisc filter was determined by an elemental analyzer (EA 1108, FISONS Instruments) according to Søndergaard \& Middelboe (1993), using glycine as a standard.

Bacterial count. The number of bacteria in the incubation medium was determined by epifluorescence methods (Porter \& Feig 1980). To the fixed sample, 4'6diamidino-2phenylindole (DAPI) was added, and the sample was kept in the dark for $10 \mathrm{~min}$. After staining, it was then filtered through a $0.2 \mu \mathrm{m}$ pore size black polycarbonate filter (Black type cyclopore membrane, Whatman). At least 2 samples were prepared from each incubation sample. With an epifluorescence microscope (BH-2, Olympus), we counted more than 400 cells sample ${ }^{-1}$, within 20 fields of view.

Fluorescence properties. EEMs of DOM from the incubated sample were obtained using a spectrofluo- rometer (F-4500, Hitachi) under the following conditions: scan ranges: 200 to $500 \mathrm{~nm}$ and 250 to $550 \mathrm{~nm}$ for excitation and emission, respectively; scan speed: $30000 \mathrm{~nm} \mathrm{~min}{ }^{-1}$; sampling interval: $5.0 \mathrm{~nm}$; excitation and emission slit width: $10 \mathrm{~nm}$; photomultiplier tube (PTM) voltage: $950 \mathrm{~V}$ for EEM fluorescence of the incubation and seawater samples and $700 \mathrm{~V}$ for the forest effluent sample. Fluorescence intensity was normalized to quinine sulfate units (QSU; $1 \mathrm{QSU}=1 \mu \mathrm{gl}^{-1}$ quinine sulfate).

Water sample for analysis of FDOM $_{\mathrm{H}}$. Water samples from Oura Bay and its adjacent forest were used for the analysis of $\mathrm{FDOM}_{\mathrm{H}}$. The filtrate of the water sample, which was used to collect the bacterial assemblage, was used as the Oura Bay DOM sample. The forest effluent was collected on 22 June 2007 and was filtered through a $0.2 \mu \mathrm{m}$ pore size filter (Anodisc, Whatman).

HPSEC. The filtrate samples $(500 \mathrm{ml})$ were desalted using a microacilyzer (S3, Asahi Chemical) until their conductivity reached $1.0 \mathrm{~ms}$. Quantities of inorganic compounds identical to those of artificial seawater were added to the forest effluent in order to avoid the effect of any difference in ionic strength before desalination. After the addition of the inorganic compounds, the forest effluent was desalted. Using a freeze dryer (FDV-2100, EYELA), the desalted samples were concentrated by 20 -fold (concentrated samples), and were stored at $-20^{\circ} \mathrm{C}$ until analysis. EEMs of the concentrated samples were compared to those of the original seawater samples, and we found little difference in the shapes of humic-like peaks between them.

MW distribution of humic-like substances in the concentrated samples was determined by high-performance liquid chromatography (HPLC, Agilent 1100 series, Agilent) with a polymer base column $(\mathrm{OH}$ Pak SB-803, Shodex). The eluent was $0.01 \mathrm{~mol} \mathrm{l}^{-1} \mathrm{NaHCO}_{3}$ buffer solution in $0.1 \mathrm{~mol} \mathrm{l}^{-1} \mathrm{NaCl}(\mathrm{pH}=8.2)$. The flow rate of the eluent was $0.50 \mathrm{ml} \mathrm{min}^{-1}$, and the injection volume was $100 \mu \mathrm{l}$. Peaks were detected by fluorescence at excitation wavelengths of $335 \mathrm{~nm}$ and emission wavelengths of $410 \mathrm{~nm}$. This set of wavelengths was determined based on the corresponding wavelengths of $\mathrm{FDOM}_{\mathrm{H}}$ obtained from the cultured sample collected on Day 90 (see 'Results'). Polystyrene sulfonate sodium salts (PSS) with MWs of 18, 8.0, 4.6, and $1.8 \mathrm{kDa}$ (Polysciences) were used as MW standards to calibrate the HPSEC system.

Photodegradation experiments of FDOM $_{\mathrm{H}}$. The concentrated sample on Day 90 (with added glucose) and the seawater from Oura Bay were used for photodegradation experiments. The water samples were enclosed in a quartz tube $(5 \mathrm{ml})$ and left for $3 \mathrm{~d}$ under natural light at the campus of the University of Tsukuba. We also prepared another set of samples in quartz tubes, 
which were wrapped in a light-shielding sheet to avoid irradiation (dark bottles). The experiment was started at 14:00 $\mathrm{h}$ local time on 30 December 2007 and samples were recovered at 14:00 h on 31 December 2007 (24 h experiment) and on 2 January 2008 (72 h experiment). The irradiated and non-irradiated samples were stored at $-20^{\circ} \mathrm{C}$ until analysis. MW distributions of $\mathrm{FDOM}_{\mathrm{H}}$ in the irradiated and non-irradiated samples were determined using HPSEC.

Radiation data of the UV range (290 to $315 \mathrm{~nm}$ ), measured at the National Institute for Environmental Studies (13.5 km south of the experimental site), were obtained from the archives of the World Ozone and Ultraviolet Radiation Data Centre (WOUDC). UV-A and photosynthetically active radiation (PAR) irradiance were estimated using the following ratio; UVB (280 to $315 \mathrm{~nm}$ ):UV-A (315 to $400 \mathrm{~nm}$ ):PAR (400 to $700 \mathrm{~nm})=1: 40: 287$ (Sugawara et al. 2003). Irradiance at wavelengths less than $290 \mathrm{~nm}$ was beyond the range of measurement, but no such irradiance was recorded during the experiment.

\section{RESULTS}

Bacterial number and DOC and POC concentration. Changes in the total number of bacteria and the DOC and POC concentrations (from which control values were subtracted) during the experiment are shown in Fig. 1. Bacterial numbers increased from $4.9 \times 10^{4}$ to $6.0 \times 10^{5} \mathrm{cells} \mathrm{ml}^{-1}$ on the first experimental day. The DOC concentration showed little change on that day, but underwent a drastic decrease after Day 1, dropping from $1266 \mu \mathrm{mol} \mathrm{C}{ }^{-1}$ (Day 1) to $486 \mu \mathrm{mol} \mathrm{C}^{-1}$ on Day 2 , and continuing to decrease to $33 \mu \mathrm{mol} \mathrm{C} \mathrm{l}^{-1}$ on

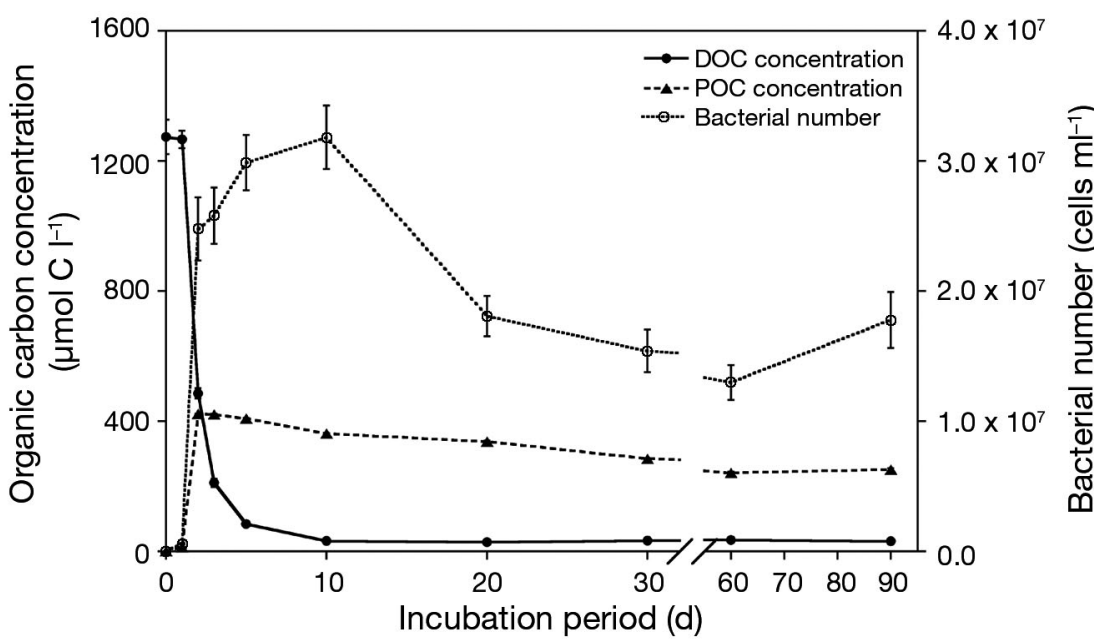

Fig. 1. Changes in dissolved organic carbon (DOC) and particulate organic carbon (POC) concentrations and in bacterial numbers during the incubation experiment. Error bars show standard deviation for duplicate incubation bottles
Day 10. Little change was observed in the DOC concentration from Day 10 to the end of the experiment $\left(32 \mu \mathrm{mol} \mathrm{C} \mathrm{^{-1 }}\right.$ ) on Day 90. A rapid double-digit increase in total bacterial numbers was noticed concomitant with the decrease in the DOC concentration from Day 1 to 2 . Those numbers continued to increase after Day 2, reaching a maximum on Day $10\left(3.2 \times 10^{7}\right.$ cells $\left.\mathrm{ml}^{-1}\right)$, then decreasing from Day 10 to Day $30\left(1.5 \times 10^{7}\right.$ cells $\mathrm{ml}^{-1}$ ) with little fluctuation noted from Day 30 to 60. The DOC concentration of the control sample slightly increased from 4 (Day 0) to 26 (Day 90) $\mu \mathrm{mol} C$ $\mathrm{l}^{-1}$ in $90 \mathrm{~d}$. Meanwhile, the POC concentration increased markedly from Day 1 to 2 concomitant with the increase in bacterial numbers, with the maximum con-

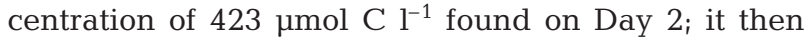
gradually decreased to $252 \mu \mathrm{mol} \mathrm{C} \mathrm{^{-1 }}$ on Day 90 . The POC concentration of the control sample showed little change (5 to $8 \mu \mathrm{mol} \mathrm{C} \mathrm{l}^{-1}$ ) during the experimental period.

PON concentration and $\mathbf{C} / \mathrm{N}$ ratio. Variations of the PON concentration and the ratio of $\mathrm{C}: \mathrm{N}$ on anodisc filter samples ( $\mathrm{C} / \mathrm{N}$ ratio) (from which control values were subtracted) throughout the experiment are shown in Fig. 2. Although the PON concentration was below the measurable limit of the analysis used on Day 0, it increased markedly from Day 1 to 2 concomitant with the increase in the POC concentration and bacterial numbers. The maximum concentration of $73 \mu \mathrm{mol} \mathrm{N} \mathrm{l}{ }^{-1}$ was found on Day 5 ; it then moderately dropped to $34 \mu \mathrm{mol} \mathrm{N} \mathrm{l^{-1 }}$ on Day 90. The PON concentration of the control sample showed little change (0 to $1 \mu \mathrm{mol} \mathrm{N}{ }^{-1}$ ) during the experimental period.

The $\mathrm{C} / \mathrm{N}$ ratio on Day 0 could not be obtained due to the low concentration of PON. The C/N ratio on Day 1 was calculated to be 4.5 , and relatively higher values were found during Days 2 to 90 (5.9 on average). The $\mathrm{C} / \mathrm{N}$ ratio of 7.6 recorded on Day 90 was the highest in this experiment, and comparatively higher than the $\mathrm{C} / \mathrm{N}$ ratio of coastal bacteria (Gundersen et al. 2002). Scanning electron microscope analysis of the filter sample of Day 90 (data not shown) suggested that bacterial extracellular mucilage represents a substantial part of POM. The rather higher $\mathrm{C} / \mathrm{N}$ ratio of POM than of bacterial cells is probably due to the presence of mucilage substances, which are mainly composed of carbon rich compounds such as carbohydrates (Salehizadeh \& Shojaosadati 2001).

Fluorescence properties of DOM. The EEM contour plots of the samples collected on Days $0,2,5,10,20$, and 


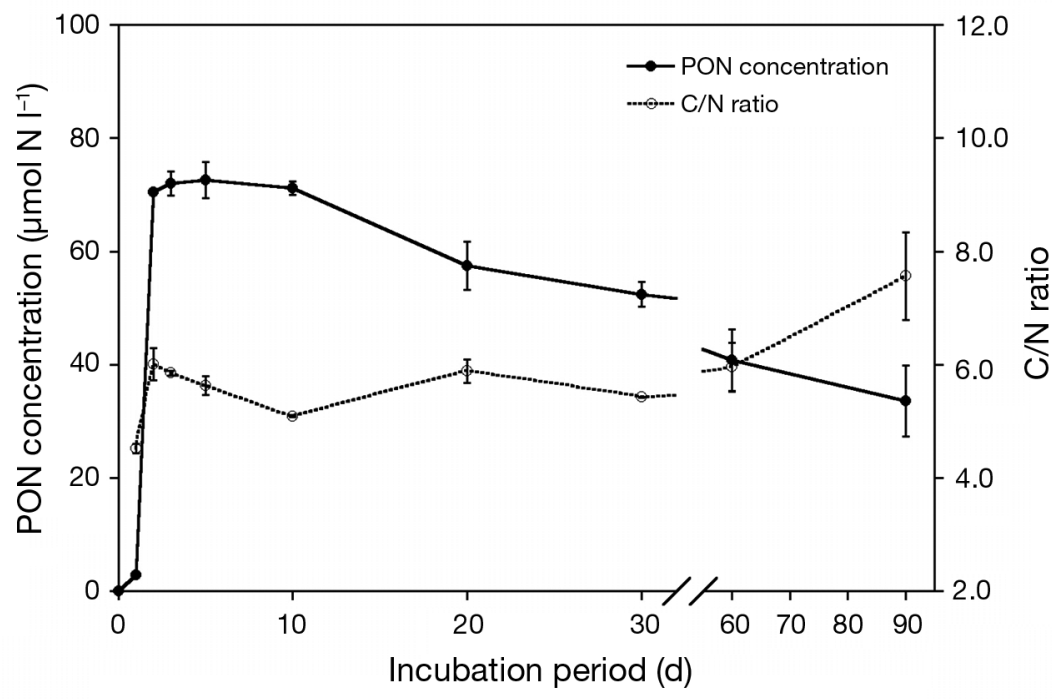

Fig. 2. Changes in particulate organic nitrogen (PON) concentrations and the ratio of $\mathrm{C}: \mathrm{N}$ on anodisc filter samples during the incubation experiment. Error bars show standard deviation for duplicate incubation bottles
(Day 2). A temporary increase in the fluorescence intensity of DOM lagged several days behind the increase in bacterial numbers until Day 20, when it reached a maximum of 5.0 QSU; it decreased to 3.2 QSU on Day 30, accounting for about $60 \%$ of the maximum on Day 20. A minor fluctuation in intensity was noticed between Days 30 and 90. The fluorescence intensity of the control samples showed no significant variation and stayed low (0.1 to 0.2 QSU) throughout the experiment.

The increase in DOC normalized QSU was slight until Day 3 due to the high concentration of glucose that was added to the culture medium, but it rapidly increased from Day 5 to 10 with a gentle increase on Days 10 to 20. After a maximum QSU/DOC ratio of 0.138 was noted on Day 20, it

90 of the experiment together with the natural seawater of Oura Bay and forest effluent are shown in Fig. 3. Although Day 0 of the experiment showed no fluorescence peak, 2 peaks were detected at the $\mathrm{Ex} / \mathrm{Em}=275 / 335$ and $315 / 415 \mathrm{~nm}$ on Day 2. These Ex/Em pairs correspond to a protein-like and humiclike fluorescence, respectively (Coble et al. 1998, Parlanti et al. 2000). These peaks became distinct after Day 2, and a shift of the humic-like fluorescence peak was found from Day $2(\mathrm{Ex} / \mathrm{Em}=315 / 415 \mathrm{~nm})$ to $10(\mathrm{Ex} / \mathrm{Em}=330 / 420 \mathrm{~nm})$. A slight shift in fluorescence was observed $(\mathrm{Ex} / \mathrm{Em}=330-340 / 410-420 \mathrm{~nm})$ after Day 10 until the end of the experiment. Additionally, 2 peaks were noticed at Ex/Em = 355-370/510-515 and 440-450/520 nm between Day 2 and 10. These peaks had features similar to the EEM contour plots of soil fulvic acid $(\mathrm{Ex} / \mathrm{Em}=$ 390/509 and 455/521 nm) reported by Lochmüller \& Saavedra (1986). The peak corresponding to FDOM $_{\mathrm{H}}$ was observed on Day 90, although its intensity was less distinct than that on Day 20. Humic-like fluorescence intensity was low in the seawater samples collected from Oura Bay. An obvious fluorescence peak was detected at Ex/ $\mathrm{Em}=323-345 / 432-447 \mathrm{~nm}$ in the forest effluent sample.

Since the DOM that remained on Day 90 could be regarded as refractory organic matter produced by bacteria, the Ex/Em pair of the humic-like peak on Day $90(E x / E m=335 / 410 \mathrm{~nm})$ was adopted to evaluate the change in the fluorescence intensity of $\mathrm{FDOM}_{\mathrm{H}}$ produced by bacteria throughout the experiment (Fig. 4). Although that intensity showed little change on Day 1, it increased from 0.1 QSU (Day 1) to 1.0 QSU dropped to 0.080 on Day 30 at almost the same ratio calculated for Days 60 and 90. This constancy suggests that the quantitative and qualitative changes in DOM were insignificant after Day 30 compared to those before that time.

MW distribution of BAC-FDOM $\mathbf{B}_{\mathbf{H}}$. The MW distribution of $\mathrm{FDOM}_{\mathrm{H}}$ derived from the bacterial assemblage that was monitored by the fluorescence intensity of $\mathrm{Ex} / \mathrm{Em}=335 / 410 \mathrm{~nm}$ is shown in Fig. 5. Only noise peaks were observed on Day 0 that may have been attributable to the $\mathrm{FDOM}_{\mathrm{H}}$ contained in the surface seawater of Oura Bay, since a small volume of seawater was added to the bacterial assemblage at the start of the experiment. The first significant change in the chromatogram was found on Day 2, when peaks were detected on the retention times at $19.7 \mathrm{~min}$ (peak A) and $22.5 \mathrm{~min}$ (peak B). An additional peak with a retention time of $25.0 \mathrm{~min}$ (peak C) was observed in the Day 5 sample, and the peak area was close to those of peaks A and B. The area of all peaks markedly increased from Days 5 to 10. By Day 20, the area of peak $\mathrm{C}$ increased to become the most prominent peak on that day. On Day 90, the intensity of peak C decreased compared to Day 20, and the additional small peak was found after peak $\mathrm{C}$.

FDOM $_{\mathrm{H}}$ in the surface water of Oura Bay was also fractionated by HPSEC (Fig. 5). Three peaks were found with retention times comparable to those observed in the incubation samples. A broad peak with a retention time of 18.8 min was also found among the constituents of $\mathrm{FDOM}_{\mathrm{H}}$ in the surface water of Oura Bay. The chromatogram of effluent from the neighboring forest revealed only 1 broad peak centered at 

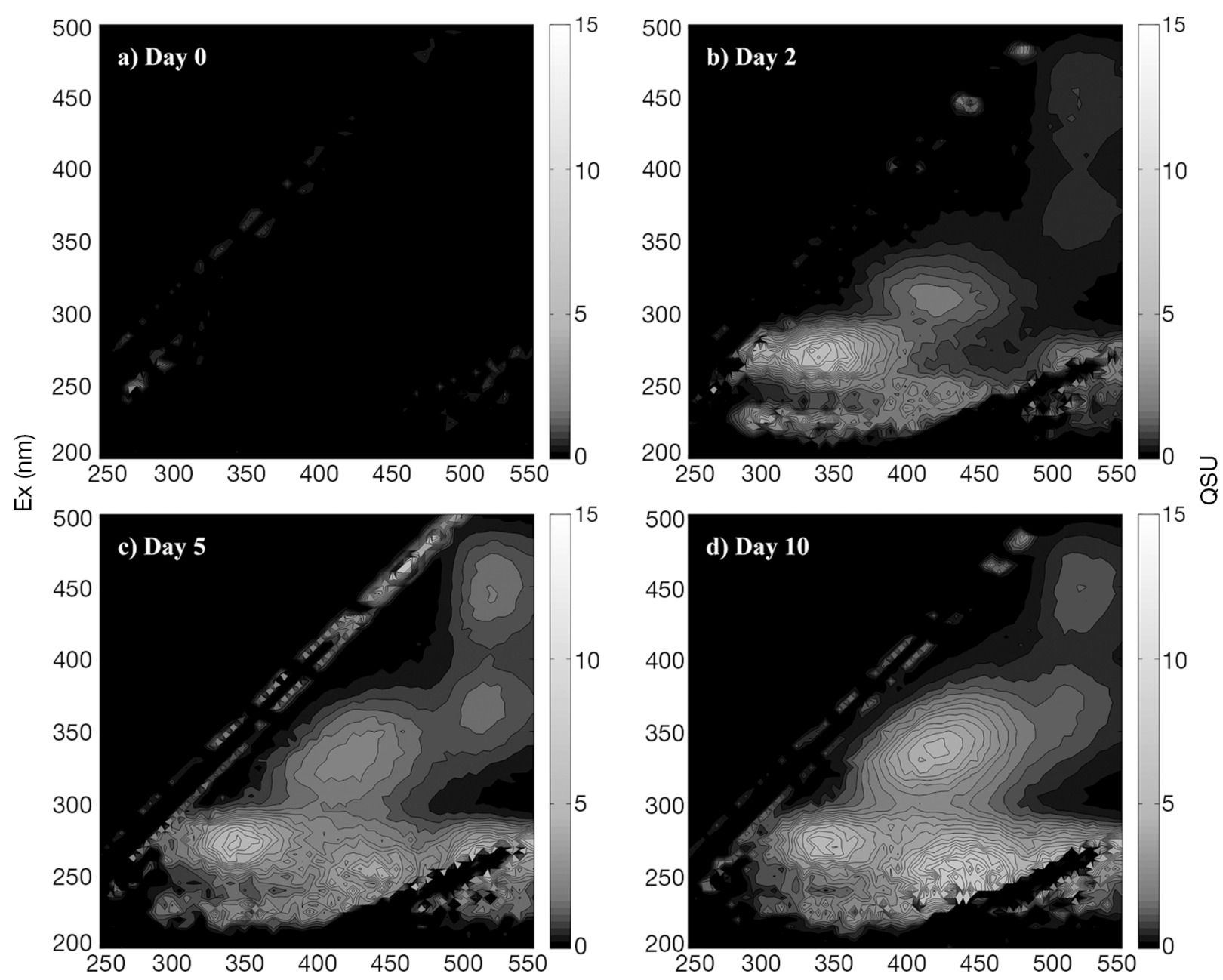

$\mathrm{Em}(\mathrm{nm})$

Fig. 3 (above and facing page). Excitation-emission matrices (EEMs) of (a-f) incubated, (g) Oura Bay, and (h) forest effluent samples. In the incubated samples, the EEM of the control sample was subtracted to eliminate background EEMs. In the Oura Bay and forest effluent samples, distilled water was used as a substitute for the control sample

$18.5 \mathrm{~min}$. The retention times of the PSS standards with MWs of $18,8.0,4.6$, and $1.8 \mathrm{kDa}$ were 15.3, 16.3, 17.0, and $17.5 \mathrm{~min}$, respectively.

Photochemical change in $\mathbf{F D O M}_{\mathbf{H}}$. The integrated UV-B irradiances for the $24 \mathrm{~h}$ and $72 \mathrm{~h}$ experiments were $5.3 \mathrm{~kJ} \mathrm{~m}^{-2}$ and $15.8 \mathrm{~kJ} \mathrm{~m}^{-2}$, respectively, whereas the corresponding integrated UV-A and PAR irradiances were estimated to be $213 \mathrm{~kJ} \mathrm{~m}^{-2}$ and $1.5 \mathrm{MJ} \mathrm{m}^{-2}$, and $634 \mathrm{~kJ} \mathrm{~m}^{-2}$ and $4.5 \mathrm{MJ} \mathrm{m}^{-2}$, respectively. The chromatograms of the irradiated and dark control samples (Day 90 and Oura Bay) are shown in Fig. 6. Little change was observed in the chromatograms of the dark sample (Fig. 6) compared to those obtained before the irradiation experiment (Fig. 5). In the irradiated sample of BAC-FDOC $\mathrm{H}_{\mathrm{H}}$ obtained on Day 90 (Fig. 6), on the other hand, a drastic difference was noticed; peak $\mathrm{C}$ had completely disappeared in the
$24 \mathrm{~h}$ experiment, and the area of peaks A and B had considerably diminished (47 and $59 \%$ of the dark control, respectively). The total peak area from 17 to $27 \mathrm{~min}$ in retention time, where peaks $\mathrm{A}, \mathrm{B}$, and $\mathrm{C}$ appeared, dropped to $43 \%$ of the dark control sample in the $24 \mathrm{~h}$ experiment. A further decrease was noticed in peak B in the $72 \mathrm{~h}$ experiment $(18 \%$ of the dark sample), but little change was observed in peak A (40\% of the dark sample). In the sample from Oura Bay, the irradiance of sunlight resulted in a decrease in the total peak area (Fig. 6, 17 to $27 \mathrm{~min}$ in retention time), accounting for $56 \%$ of the dark control sample in the $24 \mathrm{~h}$ experiment. The area of peaks A and B declined to 55 and $51 \%$ of the dark control, respectively, and peak $\mathrm{C}$ disappeared entirely in the $24 \mathrm{~h}$ experiment. The prolonged irradiation resulted in a further decrease in peak $B$, whereas the area of peak $A$ 


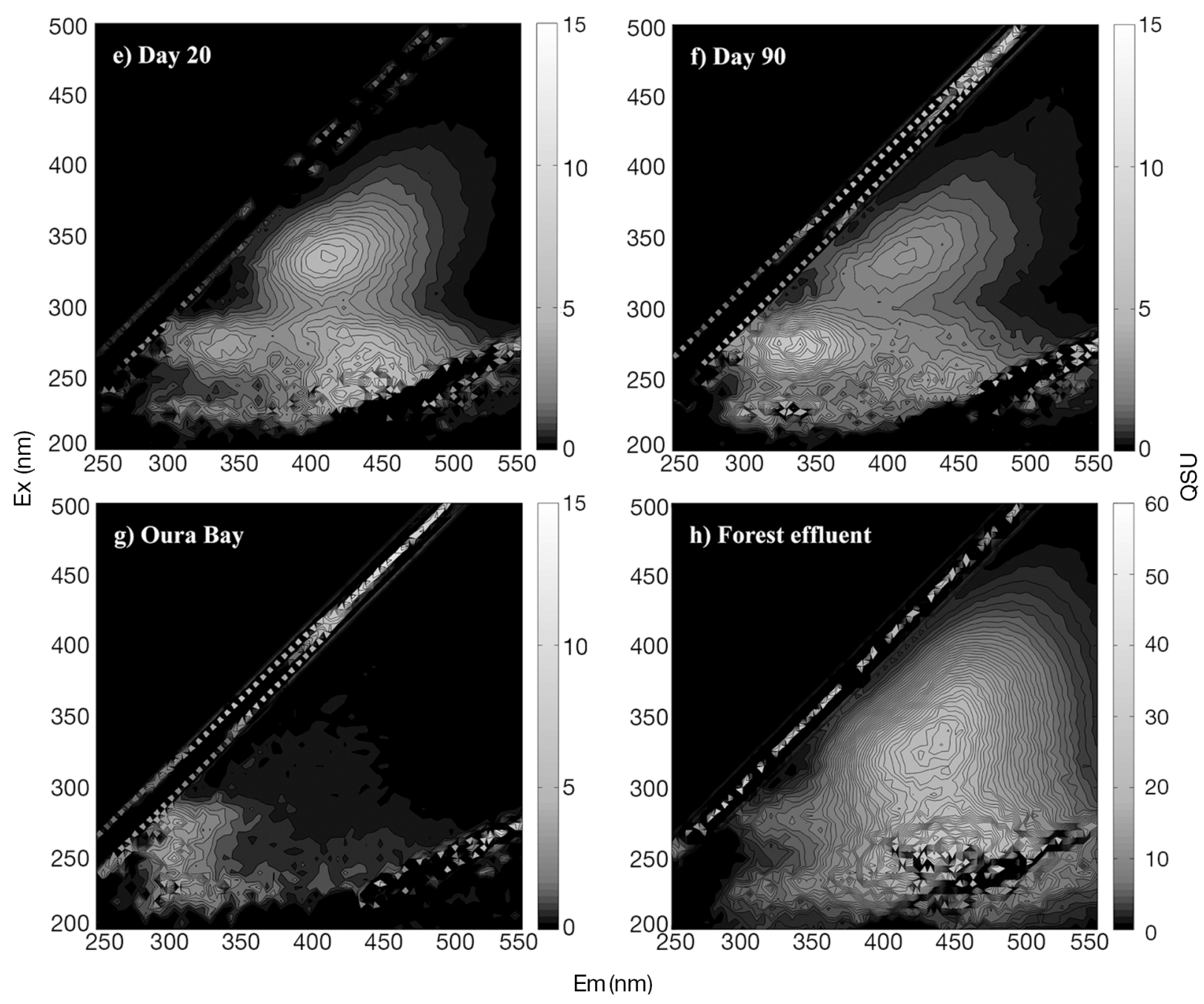

Fig. 3 (continued)

Fig. 4. Changes in bacteria-derived humic-like fluorescent dissolved organic matter $\left(\mathrm{BAC}-\mathrm{FDOM}_{\mathrm{H}}\right)$ and QSU/DOC ratio over the course of the incubation experiment. Fluorescence intensity at excitation $/$ emission $=335 / 410 \mathrm{~nm}$ normalized as QSU (1 QSU $=1 \mu g \mathrm{l}^{-1}$ quinine sulphate) is plotted. Error bars show standard deviation for duplicate incubation bottles
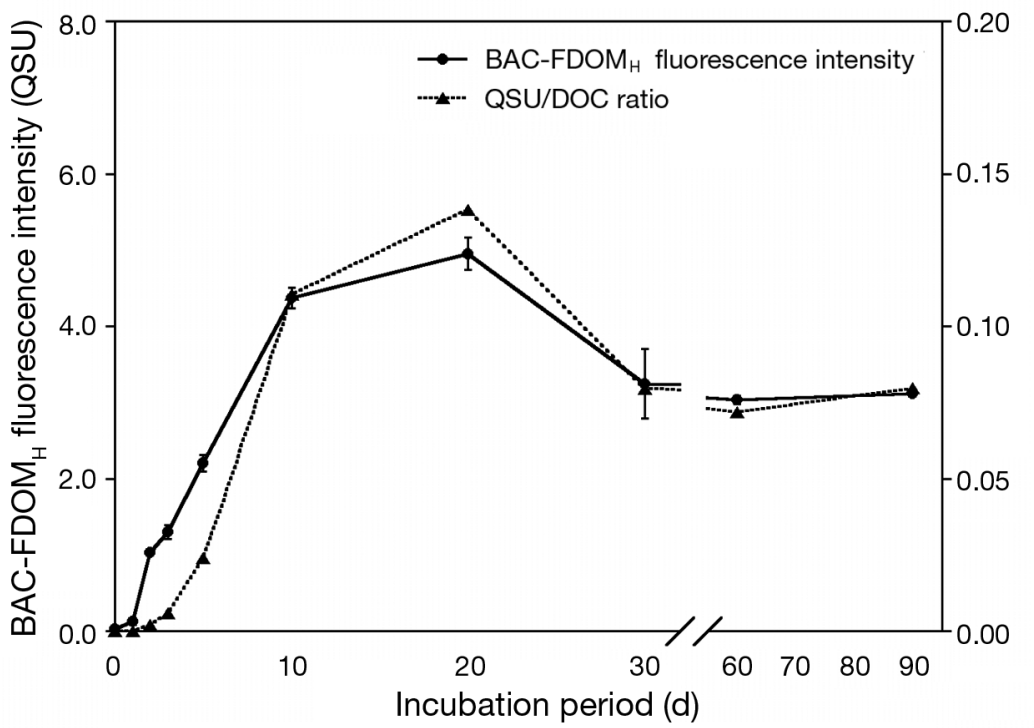

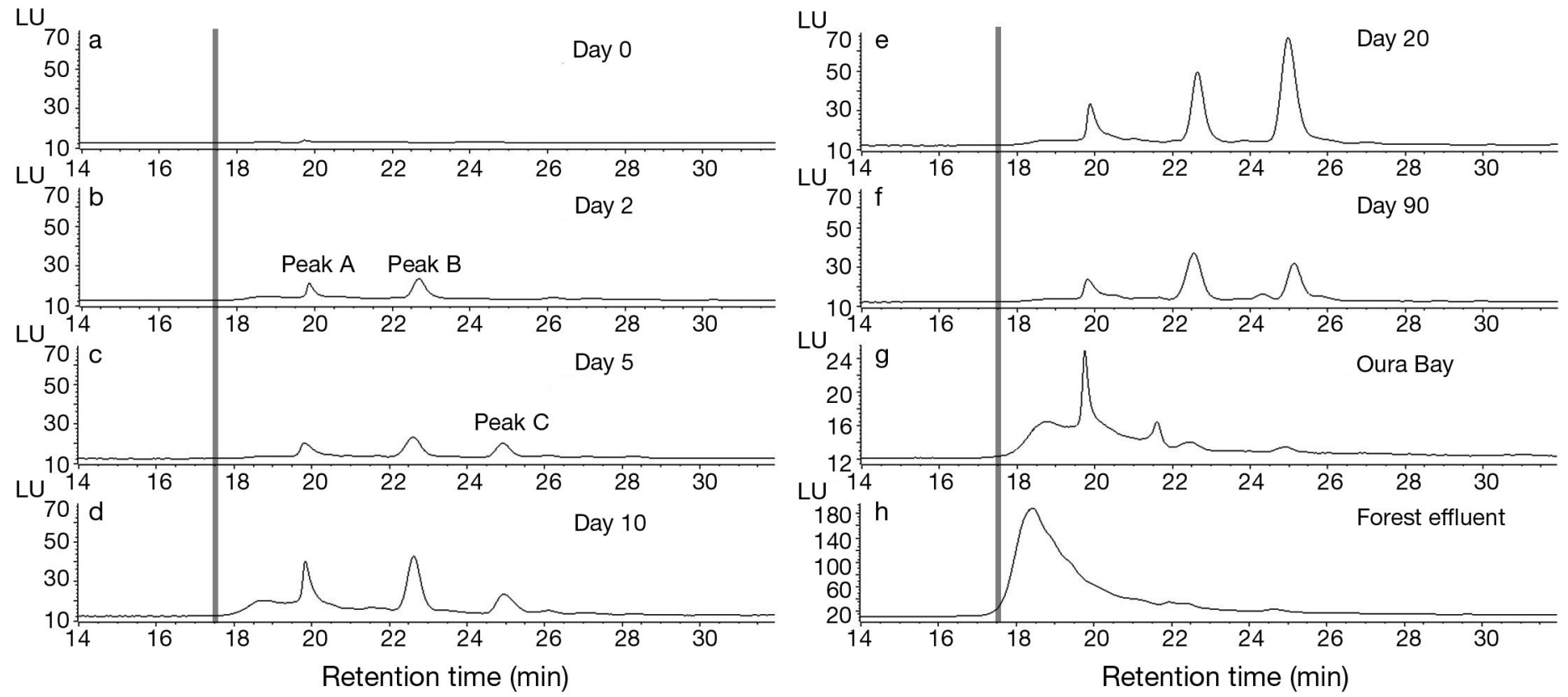

Fig. 5. High-performance size-exclusion chromatography of $\mathrm{FDOM}_{\mathrm{H}}(\mathrm{a}-\mathrm{f})$ incubated samples, (g) Oura Bay samples, and (h) forest effluent samples. Peaks were detected by fluorescence at excitation wavelengths of $335 \mathrm{~nm}$ and emission wavelengths of $410 \mathrm{~nm}$. Shaded bar shows the retention time of polystyrene sulfonate sodium salts (PSS, $1.8 \mathrm{kDa}$ ). LU = luminescence units
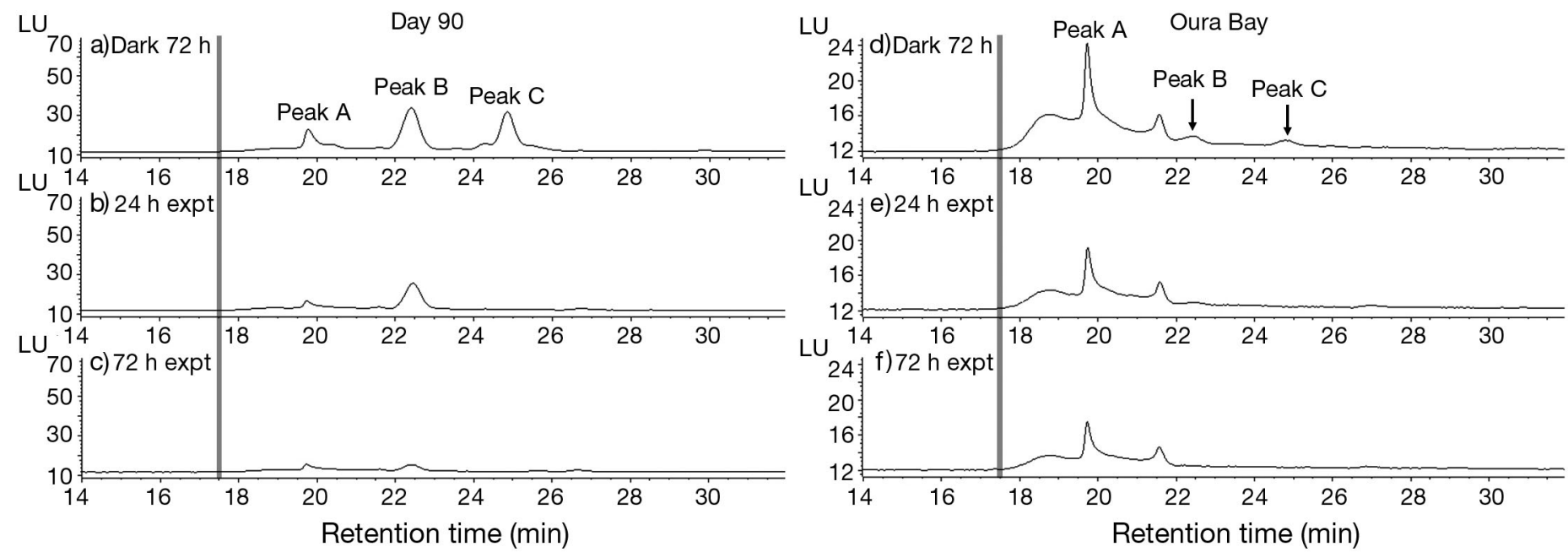

Fig. 6. High-performance size-exclusion chromatography of $\mathrm{FDOM}_{\mathrm{H}}$ solar irradiated (24 and $72 \mathrm{~h}$ experiments) and nonirradiated (dark, $72 \mathrm{~h}$ ) samples of $(\mathrm{a}, \mathrm{b}, \mathrm{c})$ the incubation experiment on Day 90 and $(\mathrm{d}, \mathrm{e}, \mathrm{f})$ from Oura Bay. Shaded bar shows the retention time of polystyrene sulfonate sodium salts (PSS, $1.8 \mathrm{kDa}$ ). LU = luminescence units

showed no significant decrease. The peak at $21.6 \mathrm{~min}$, which was observed only for the Oura Bay sample, was maintained even in the $72 \mathrm{~h}$ experiment. The difference in the chromatogram patterns between the irradiated and non-irradiated samples from Oura Bay was less obvious compared to the BAC-FDOM $\mathrm{B}_{\mathrm{H}}$ obtained from the $90 \mathrm{~d}$ incubation.

\section{DISCUSSION}

\section{Production of $\mathrm{FDOM}_{\mathrm{H}}$ by the bacterial assemblage}

Marine FDOM and chromophoric dissolved organic matter (CDOM) play important roles in the marine environment. Our knowledge concerning the distribution 
and dynamics of marine FDOM and CDOM has rapidly progressed during this decade. The vertical distribution of the fluorescence intensity of $\mathrm{FDOM}_{\mathrm{H}}$, with low intensity in the surface layer and high intensity in the deep layer (Chen \& Bada 1992), suggests that the production and destruction of $\mathrm{FDOM}_{\mathrm{H}}$ are different from those of bulk DOC, which shows a high concentration in the surface layer. The close relationship between the fluorescence intensity and inorganic nutrients or apparent oxygen utilization strongly suggests that the production of marine $\mathrm{FDOM}_{\mathrm{H}}$ is associated with the microbial decomposition process (Nieto-Cid et al. 2005). Consequently, bacteria have been proposed as the most likely producer of marine FDOM $_{\mathrm{H}}$.

In this study, we used EEMS, which has been routinely applied to estimate the composition of fluorescing compounds in DOM (Coble et al. 1998, Parlanti et al. 2000). The EEMs obtained for the culture medium of bacteria comprised 2 peaks, whose maximum fluorescence intensity was centered at Ex/Em = 265-280/ 330-355 nm and 315-340/410-420 nm throughout the experiment. According to Coble et al. (1998), the former peak corresponds to protein-like substances and the latter to $\mathrm{FDOM}_{\mathrm{H}}$. Although a small amount of $\mathrm{FDOM}_{\mathrm{H}}$, reflecting the addition of natural seawater collected from Oura Bay, should have existed in the sample on Day 0 at the start of the experiment, the peak of $\mathrm{FDOM}_{\mathrm{H}}$ was not detectable by EEMS, probably due to the low concentration. Although the peak became apparent after Day 2, both the excitation and emission wavelengths were shorter than the reported values of seawater of $\mathrm{FDOM}_{\mathrm{H}}$. The peak corresponding to $\mathrm{FDOM}_{\mathrm{H}}$ was clearly visible from Day 5 , showing that it was newly produced. Since the culture medium was composed of inorganic salts, glucose, and the GF/F filtrate of natural seawater (which includes the bacterial assemblage), it was apparent that $\mathrm{FDOM}_{\mathrm{H}}$ was produced via bacterial activity.

Several experimental attempts have been carried out to elucidate the relationship between microbial abundance and the concentration of $\mathrm{FDOM}_{\mathrm{H}}$ and/or CDOM by the incubation of a natural microbial population. Some studies have found that the temporal changes in their concentration correlated with those in bacterial abundance (Nelson et al. 2004, Yamashita \& Tanoue 2004 b), indicating that FDOM $_{\mathrm{H}}$ was produced as a byproduct of the degradation of organic matter by bacteria. Most studies, however, discovered that microorganisms other than bacteria, such as phytoplankton (Nelson et al. 2004, Yamashita \& Tanoue 2004b) or zooplankton (Steinberg et al. 2004), coexisted in their experimental systems. Thus, it is rather difficult to assert that FDOM $\mathrm{H}_{\mathrm{H}}$ was produced solely by bacteria in the above-mentioned studies. Several experiments were designed to confirm the bacterial ability to pro- duce BAC-FDOM $\mathrm{M}_{\mathrm{H}}$ using glucose as an organic carbon source, and our measurements of EEMs clearly confirm that bacteria are responsible for the production of marine FDOM $_{\mathrm{H}}$. These results are in agreement with those of Kramer \& Herndl (2004), who determined the BAC-FDOM $\mathrm{H}_{\mathrm{H}}$ by measurements of the fluorescence intensity at a single combination of wavelengths (Ex/ $\mathrm{Em}=350 / 450 \mathrm{~nm})$.

The fluorescence intensity of BAC-FDOM $\mathrm{B}_{\mathrm{H}}$ increased linearly from Days 1 to 10 at a rate of ca. $0.48 \mathrm{QSU} \mathrm{d}^{-1}$. This steady increase does not reflect the change in the bacterial biomass, which showed a rapid rise between Days 2 and 3 with only a slight increase during Days 3 to 10 . The maximum fluorescence intensity of BAC-FDOM $\mathrm{H}_{\mathrm{H}}$ coincided with the late stage of a logarithmic growth phase. These time courses of bacterial biomass and QSU of BAC-FDOM $\mathrm{H}_{\mathrm{H}}$ are virtually comparable with the observations made by Kramer \& Herndl (2004). Thus, the inconsistency between bacterial growth and the fluorescence intensity suggests that the production rate of $\mathrm{BAC}-\mathrm{FDOM}_{\mathrm{H}}$ does not reflect the bacterial growth rate, and that the active production of BAC-FDOM $\mathrm{H}_{\mathrm{H}}$ lags behind the production of cellular biomolecules. Viral lysis has been considered among the most important phenomena that cause the release of bacterial cellular organic matter as DOM (Bratbak et al. 1994, Middelboe \& Jørgensen 2006). The concomitant increase in the fluorescence intensity and decrease in bacterial cell number during Days 10 to 20 suggests the possible contribution of viral lysis to the production of BAC-FDOM $\mathrm{H}_{\mathrm{H}}$. Although grazing by flagellates could cause the decrease in bacterial biomass and the increase in DOM (Middelboe \& Jørgensen 2006), it would be unlikely in this study because flagellates should be removed by filtration of seawater using glass fiber filters (GF/F, Whatman) to prepare the bacterial assemblage.

\section{MW distribution of BAC-FDOM ${ }_{\mathrm{H}}$}

The present study may represent the first systematic analysis of BAC-FDOM $\mathrm{H}_{\mathrm{H}}$ by HPSEC, although considerable valuable information on freshwater humic substances has already been accumulated (Chin et al. 1994, Peuravuori \& Pihlaja 1997). In our study, the use of electric desalinization made it possible to separate BAC-FDOM $\mathrm{H}_{\mathrm{H}}$ by HPSEC, demonstrating that BACFDOM $_{\mathrm{H}}$ comprises multiple components. The elution pattern strongly suggests that BAC-FDOM $\mathrm{H}_{\mathrm{H}}$ from the natural bacterial assemblage from Oura Bay is composed of $3 \mathrm{MW}$ groups having comparable fluorescence properties.

PSS has usually been applied to elucidate the relationship between the retention time and the MW of 
humic substances in freshwater environments (Chin et al. 1994, Peuravuori \& Pihlaja 1997). We added the scale of MW to the retention time by the elution of PSS. The retention times of PSS with MWs from $18 \mathrm{kDa}$ to $1.8 \mathrm{kDa}$ ranged from 15.3 to $17.5 \mathrm{~min}$; all standards showed shorter retention times than those of FDOM $_{\mathrm{H}}$. When one assumes that the retention times of PSS are directly comparable to those of BAC-FDOM $\mathrm{H}_{\mathrm{H}}$, the

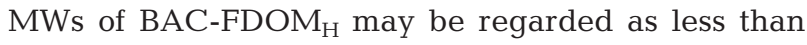
$1.8 \mathrm{kDa}$. This estimation is comparable to the results of Dittmar \& Kattner (2003), who showed that nominal molecular masses of humic substance from a coastal area amounted to less than $600 \mathrm{~g} \mathrm{~mol}^{-1}$. Estimates of the MW of $\mathrm{FDOM}_{\mathrm{H}}$ have been carried out by methods other than HPSEC using ultrafiltration. Midorikawa \& Tanoue (1998) fractionated FDOM $_{\mathrm{H}}$ from the surface layer of the North Pacific, and reported that the low MW fractions less than $1 \mathrm{kDa}$ accounted for 65 to $80 \%$ of total $\mathrm{FDOM}_{\mathrm{H}}$. The predominance of MW fractions below $1 \mathrm{kDa}$ was also reported for $\mathrm{FDOM}_{\mathrm{H}}$ using flow field-flow fractionation (Mopper et al. 1996). Thus, the estimation of MW by HPSEC in the present study agrees with these previous findings. Recent studies on the relationship between MW and the biological availability of oceanic DOM demonstrated that a low MW fraction $(<1 \mathrm{kDa})$ is more recalcitrant than a high one (>1 kDa; Amon \& Benner 1994). It is possible that the production of low MW FDOM $\mathrm{H}_{\mathrm{H}}$ by bacteria is related to the bulk refractory properties of low marine MW DOM, since the refractory property of the latter is mainly due to altered biomolecules that are not measured as carbohydrates, proteins, and amino acids (Hama et al. 2004).

\section{Biodegradability of BAC- FDOM $_{H}$}

Marine humic substances are among the most biorefractory DOM (Aiken et al. 1985, Lara \& Thomas 1995). In our study, however, the decrease in fluorescence intensity that was noticed from Days 20 to 30 accounted for about $40 \%$ of the maximum value on Day 20. This may be because glucose, which was the sole carbon and energy source for bacterial growth, had probably been used up within the first $10 \mathrm{~d}$ when bacterial numbers were at a maximum. Thus, it is quite possible that the bacteria used humic substances as their energy substrate during Days 20 to 30, indicating that, to some extent, BAC-FDOM $\mathrm{H}_{\mathrm{H}}$ is composed of biodegradable compounds. This is supported by the finding that bacteria can utilize humic substance when no other organic compounds are available (Bussmann 1999).

After Day 30, the fluorescence intensity showed no significant decrease, and $63 \%$ of the maximum intensity on Day 20 remained at the end of the experiment
(Day 90). This high remaining ratio (the ratio at the end of the experiment to the maximum value on Day 20) likely suggests that more than half of BAC-FDOM $\mathrm{H}_{\mathrm{H}}$ is composed of biological recalcitrant compounds. The remaining ratio reported for specific organic compounds or fractions determined by bacterial culture experiments can be compared to the BAC-FDOM $\mathrm{H}_{\mathrm{H}}$ calculated in the present study to assess its biodegradability. Kitayama et al. (2007) reported that on Day 60, the concentration of dissolved D-alanine, which is a component of peptidoglycan (no sampling was done on Day 90 in their experiment), accounted for $26 \%$ of their maximum concentration. Although recent studies have cast doubt on the recalcitrant property of bacterial peptidoglycan (Kaiser \& Benner 2008), others have identified it as one of the recalcitrant bacterial products (Kitayama et al. 2007). The remaining ratio of BAC-FDOM ${ }_{\mathrm{H}}$ determined in this study (63\%) on Day 60 was considerably higher than that of peptidoglycan $(26 \%)$. This comparison suggests that BAC-FDOM $\mathrm{H}_{\mathrm{H}}$ is more stable and will survive for a longer time than peptidoglycan. Hama et al. (2004) observed that the refractory organic compounds whose MW is less than $10 \mathrm{kDa}$ were produced within the first week after the decomposition of phytoplankton photosynthetic products began. The remaining ratio on Day 60 of this low MW DOC fraction was about $60 \%$, being roughly comparable to the BAC-FDOM ${ }_{H}$ in the present study. This recalcitrant fraction of low MW DOC contained little or no carbohydrates. Ogawa et al. (2001) also reported the production of refractory DOM during the incubation of bacteria that were supplemented with labile organic matter, and showed that most refractory DOM is not characterized by amino acid and carbohydrates. These results suggest that the production of $\mathrm{FDOM}_{\mathrm{H}}$ by bacteria is an important process that converts labile biomolecules to recalcitrant DOM in marine environments and is accompanied by molecular alteration.

\section{Relationship between BAC-FDOM $\mathrm{M}_{\mathrm{H}}$ and oceanic FDOM $_{\mathbf{H}}$}

The chromatogram of the surface seawater sample from Oura Bay, where the bacterial assemblage was collected, was characterized by a broad peak centered at $18.8 \mathrm{~min}$ and a large sharp peak at $19.7 \mathrm{~min}$, which corresponds to peak A in BAC-FDOM $\mathrm{H}_{\mathrm{H}}$ some additional small peaks appeared at 21.6, 22.5, and $24.9 \mathrm{~min}$, with the latter 2 being comparable, respectively, to peaks $\mathrm{B}$ and $\mathrm{C}$ in $\mathrm{BAC}-\mathrm{FDOM}_{\mathrm{H}}$. The presence of peaks whose retention times are identical to those in a bacterial culture indicated the contribution of bacteria as producers of $\mathrm{FDOM}_{\mathrm{H}}$ in Oura Bay. However, obvious inconsistencies remain between the 2 chromatograms, 
such as the trace amounts of peaks B and C, and the presence of a broad peak in the natural seawater from Oura Bay. However, the chromatograms of the irradiation experiment and of the effluent from the adjacent forest probably fill the gap between the 2 chromatograms of $\mathrm{BAC}-\mathrm{FDOM}_{\mathrm{H}}$ and that in the seawater from Oura Bay.

One of the obvious differences is the small height of peaks B and C in the sample from Oura Bay. However, the photodegradation experiment clearly showed that those 2 peaks were susceptible to solar radiation; peak $\mathrm{C}$ completely disappeared after the $24 \mathrm{~h}$ experiment, as did peak B after $72 \mathrm{~h}$. Thus, it is most likely that the fluorophores of peaks B and C, which were possibly supplied by the bacterial activity in Oura Bay, would be photodegraded, with only a minor portion remaining as constituents of $\mathrm{FDOM}_{\mathrm{H}}$ in the surface water.

Another clear disparity in the MW composition is the presence of a broad peak centered at $18.8 \mathrm{~min}$ in the sample from Oura Bay; no corresponding peak can be observed in the BAC-FDOM $\mathrm{H}_{\mathrm{H}}$. Oura Bay is adjacent to a dense forest between steep cliffs, and the effluent of water from the forest always flows to the bay. An EEMS analysis showed that the forest effluent contained a high concentration of $\mathrm{FDOM}_{\mathrm{H}}$, whose peak was found at $\mathrm{Ex} / \mathrm{Em}=340 / 440 \mathrm{~nm}$; the emission wavelength was higher than that observed in BAC-FDOM $\mathrm{H}_{\mathrm{H}}$. An HPSEC analysis of the FDOM $_{\mathrm{H}}$ supplied from the forest effluent showed that it is composed of only one component centered at $18.8 \mathrm{~min}$ (Fig. 5). It is noteworthy that both the effluent's retention time and gross shape (broad with a substantial tailing peak) of the forest effluent are reproduced in the seawater from Oura Bay. This similarity of elution volume and peak shape may suggest that $\mathrm{FDOM}_{\mathrm{H}}$ originated from the neighboring forest and accounts for a substantial part of FDOM $_{\mathrm{H}}$ in Oura Bay, although a quantitative estimation has not been attempted. Terrestrial FDOM $\mathrm{F}_{\mathrm{H}}$ other than from the forest effluent is probably supplied from the inflow of a river into the bay, although its flow rate is usually low. The presence of a peak with a retention time of $21.6 \mathrm{~min}$, which has never been observed in the chromatograms of BAC-FDOM $\mathrm{H}_{\mathrm{H}}$, indicates the presence of $\mathrm{FDOM}_{\mathrm{H}}$ of additional origin such as sediment, zooplankton, macroalgae, and other substances, which were not examined in the present study.

Although peaks $\mathrm{B}$ and $\mathrm{C}$ of $\mathrm{BAC}-\mathrm{FDOM}_{\mathrm{H}}$ were observed in only trace amounts in the FDOM $_{\mathrm{H}}$ from Oura Bay, a sharp peak was found at the same retention time as peak $\mathrm{A}$ in the chromatogram. This implies that the $\mathrm{FDOM}_{\mathrm{H}}$ constituting peak $\mathrm{A}$ in the surface water from Oura Bay originated from in situ bacterial activity. This assumption is supported by the fact that peak $\mathrm{A}$ is most resistant to photodegradation; $40 \%$ of the fluorescence intensity was measurable after the
$72 \mathrm{~h}$ experiment. Consequently, the specific fraction of the BAC-FDOM $\mathrm{H}_{\mathrm{H}}$ produced as by-products of bacteria in the seawater is not fully photodegraded and is likely to constitute $\mathrm{FDOM}_{\mathrm{H}}$ in the surface layer of coastal waters together with terrestrial $\mathrm{FDOM}_{\mathrm{H}}$. Although EEMS have already been used in an attempt to distinguish between autochthonous and terrestrial organic matter in coastal environments (Stedmon et al. 2007), further analysis of the MW composition may make it possible to determine the origin and the biogeochemical alterations of $\mathrm{FDOM}_{\mathrm{H}}$.

Acknowledgements. We thank the members of the Shimoda Marine Research Center, University of Tsukuba, for their generous assistance in the water sample collection. We thank the Chemical Analysis Center, University of Tsukuba, for the use of their spectrofluorometer. We also thank 2 anonymous reviewers for their helpful comments. This work was supported by grants from the Ministry of Education, Culture, Sports, Science, and Technology, Japan (Nos. 14340166 and 19310003), the Sasakawa Scientific Research Grant, The Japan Science Society, and the Steel Industry Foundation for the Advancement of Environmental Protection Technology.

\section{LITERATURE CITED}

Aiken GR, McKnight DM, Wershaw RL, MacCarthy P (1985) An introduction to humic substances in soil, sediment and water. In: Aiken GR, McKnight DM, Wershaw RL, MacCarthy $\mathrm{P}$ (eds) Humic substance in soil, sediment, and water. John Wiley \& Sons, New York, p 1-9

Amon RMW, Benner R (1994) Rapid cycling of high-molecular-weight dissolved organic matter in the ocean. Nature 369:549-552

Benner R (2002) Chemical composition and reactivity. In: Hansell AD, Carlson CA (eds) Biogeochemistry of marine dissolved organic matter. Academic Press, San Diego, CA, p 59-90

Bratbak G, Thingstad F, Heldal M (1994) Viruses and the microbial loop. Microb Ecol 28:209-221

> Bussmann I (1999) Bacterial utilization of humic substances from the Arctic Ocean. Aquat Microb Ecol 19:37-45

Chen RF, Bada JL (1992) The fluorescence of dissolved organic matter in seawater. Mar Chem 37:191-221

Chen ZQ, Hu CM, Conmy RN, Muller-Karger F, Swarzenski P (2007) Colored dissolved organic matter in Tampa Bay, Florida. Mar Chem 104:98-109

> Chin YP, Aiken G, Oloughlin E (1994) Molecular weight, polydispersity, and spectroscopic properties of aquatic humic substances. Environ Sci Technol 28:1853-1858

Coble PG, Del Castillo CE, Avril B (1998) Distribution and optical properties of CDOM in the Arabian Sea during the 1995 Southwest Monsoon. Deep-Sea Res II 45:2195-2223

Dittmar T, Kattner G (2003) Recalcitrant dissolved organic matter in the ocean: major contribution of small amphiphilics. Mar Chem 82:115-123

Gundersen K, Heldal M, Norland S, Purdie DA, Knap AH (2002) Elemental C, N, and P cell content of individual bacteria collected at the Bermuda Atlantic Time-series Study (BATS) site. Limnol Oceanogr 47:1525-1530

Hama T, Yanagi K, Hama J (2004) Decrease in molecular weight of photosynthetic products of marine phytoplankton during early diagenesis. Limnol Oceanogr 49:471-481 
Hedges JI (1992) Global biogeochemical cycles: progress and problems. Mar Chem 39:67-93

Kaiser K, Benner R (2008) Major bacterial contribution to the ocean reservoir of detrital organic carbon and nitrogen. Limnol Oceanogr 53:99-112

Kitayama K, Hama T, Yanagi K (2007) Bioreactivity of peptidoglycan in seawater. Aquat Microb Ecol 46:85-93

Kramer GD, Herndl GJ (2004) Photo- and bioreactivity of chromophoric dissolved organic matter produced by marine bacterioplankton. Aquat Microb Ecol 36:239-246

Lara RJ, Thomas DN (1995) Formation of recalcitrant organic matter: humification dynamics of algal derived dissolved organic carbon and its hydrophobic fractions. Mar Chem 51:193-199

Lochmüller C, Saavedra S (1986) Conformational changes in a soil fulvic acid measured by time-dependent fluorescence depolarization. Anal Chem 58:1978-1981

Middelboe M, Jørgensen N (2006) Viral lysis of bacteria: an important source of dissolved amino acids and cell wall compounds. J Mar Biol Assoc UK 86:605-612

Midorikawa T, Tanoue E (1998) Molecular masses and chromophoric properties of dissolved organic ligands for copper(II) in oceanic water. Mar Chem 62:219-239

Mopper K, Zhou XL, Kieber RJ, Kieber DJ, Sikorski RJ, Jones RD (1991) Photochemical degradation of dissolved organic carbon and its impact on the oceanic carbon cycle. Nature 353:60-62

Mopper K, Feng ZM, Bentjen SB, Chen RF (1996) Effects of cross-flow filtration on the absorption and fluorescence properties of seawater. Mar Chem 55:53-74

Moran MA, Sheldon WM, Zepp RG (2000) Carbon loss and optical property changes during long-term photochemical and biological degradation of estuarine dissolved organic matter. Limnol Oceanogr 45:1254-1264

Nelson NB, Carlson CA, Steinberg DK (2004) Production of chromophoric dissolved organic matter by Sargasso Sea microbes. Mar Chem 89:273-287

Nielsen T, Ekelund NGA (1993) Effect of UV-B radiation and humic substances on growth and motility of Gyrodinium aureolum. Limnol Oceanogr 38:1570-1575

> Nieto-Cid M, Álvarez-Salgado XA, Gago J, Pérez FF (2005) DOM fluorescence, a tracer for biogeochemical processes in a coastal upwelling system (NW Iberian Peninsula). Mar Ecol Prog Ser 297:33-50

Obernosterer I, Reitner B, Herndl GJ (1999) Contrasting effects of solar radiation on dissolved organic matter and its bioavailability to marine bacterioplankton. Limnol Oceanogr 44:1645-1654

Ogawa H, Amagai Y, Koike I, Kaiser K, Benner R (2001) Production of refractory dissolved organic matter by bacteria. Science 292:917-920

Parlanti E, Worz K, Geoffroy L, Lamotte M (2000) Dissolved organic matter fluorescence spectroscopy as a tool to estimate biological activity in a coastal zone submitted to

Editorial responsibility: Lars Tranvik,

Uppsala, Sweden anthropogenic inputs. Org Geochem 31:1765-1781

> Parlanti E, Morin B, Vacher L (2002) Combined 3D-spectrofluorometry, high performance liquid chromatography and capillary electrophoresis for the characterization of dissolved organic matter in natural waters. Org Geochem 33:221-236

- Peuravuori J, Pihlaja K (1997) Molecular size distribution and spectroscopic properties of aquatic humic substances. Anal Chim Acta 337:133-149

Porter KG, Feig YS (1980) The use of DAPI for identifying and counting aquatic microflora. Limnol Oceanogr 25:943-948

Salehizadeh H, Shojaosadati SA (2001) Extracellular biopolymeric flocculants: recent trends and biotechnological importance. Biotechnol Adv 19:371-385

Sharp JH, Peltzer ET, Alperin MJ, Cauwet G and others (1993) Procedures subgroup report. Mar Chem 41:37-49

Søndergaard M, Middelboe M (1993) Measurements of particulate organic carbon: a note on the use of glass fiber (GF/F) and anodisc filters. Arch Hydrobiol 127:73-85

Stedmon CA, Markager S (2005) Tracing the production and degradation of autochthonous fractions of dissolved organic matter by fluorescence analysis. Limnol Oceanogr 50:1415-1426

Stedmon CA, Markager S, Bro R (2003) Tracing dissolved organic matter in aquatic environments using a new approach to fluorescence spectroscopy. Mar Chem 82: $239-254$

Stedmon CA, Thomas DN, Granskog M, Kaartokallio $\mathrm{H}$, Papadimitriou S, Kuosa H (2007) Characteristics of dissolved organic matter in Baltic coastal sea ice: allochthonous or autochthonous origins? Environ Sci Technol 41: 7273-7279

Steinberg DK, Nelson NB, Carlson CA, Prusak AC (2004) Production of chromophoric dissolved organic matter (CDOM) in the open ocean by zooplankton and the colonial cyanobacterium Trichodesmium spp. Mar Ecol Prog Ser 267:45-56

Sugawara T, Hamasaki K, Toda T, Kikuchi T, Taguchi S (2003) Response of natural phytoplankton assemblages to solar ultraviolet radiation (UV-B) in the coastal water. Hydrobiologia 493:17-26

Yamashita Y, Tanoue E (2004a) Chemical characteristics of amino acid-containing dissolved organic matter in seawater. Org Geochem 35:679-692

Yamashita Y, Tanoue E (2004b) In situ production of chromophoric dissolved organic matter in coastal environments. Geophys Res Lett 31, L14302, doi:10.1029/2004GL019734

- Yamashita Y, Tanoue E (2008) Production of bio-refractory fluorescent dissolved organic matter in the ocean interior. Nature Geosci 1:579-582

Yamashita Y, Tsukasaki A, Nishida T, Tanoue E (2007) Vertical and horizontal distribution of fluorescent dissolved organic matter in the Southern Ocean. Mar Chem 106: 498-509

Submitted: December 16, 2008; Accepted: July 7, 2009

Proofs received from author(s): October 30, 2009 